\title{
Reactive Migration: Sociological Perspectives On Refugee Movements*
}

\author{
ANTHONY H. RICHMOND \\ Centre for Refugee Studies, York University, Toronto
}

\begin{abstract}
Sociological theories of migration and refugee movements are reviewed and revised in the light of recent developments in structuration theory. Specifically, the dichotomy between 'voluntary' and 'involuntary' or forced migration is replaced by a continuum between proactive and reactive migration. A systems model is proposed which identifies predisposing factors, structural constraints, precipitating events, enabling circumstances and system feedback. A multivariate typology of reactive migration is described and some policy conclusions drawn.
\end{abstract}

\section{Introduction}

Sociologists studying migration usually begin by distinguishing between voluntary and involuntary, or 'forced', migration. Examples of the latter included exiles, the slave trade, mass expulsions and movements consequent upon religious or political persecution. More complex typologies distinguished the level of development of the society in question and the consequences of the migration for the social system of the receiving society (Fairchild 1925; Petersen 1958). Voluntary movements were assumed to result from some combination of 'push' and 'pull' factors (which included economic, political and social forces), modified by the effect of intervening opportunities and obstacles. Lee (1965, repr. Jackson 1969), put forward a theory of migration which assumed that a balance of positive and negative factors 'must be enough to overcome the natural inertia which always exists'. However, there is no evidence to support the idea of a 'natural inertia' any more than a 'natural wanderlust'. The plus and minus influences Lee postulated were a mixture of socio-economic and socio-psychological variables that were insufficiently specific. He listed a number of hypotheses concerning the volume of migration, streams and counter-streams, and the characteristics of migrants. His only reference to refugees was the suggestion that the 'degree of positive selection increases with the difficulty of the intervening obstacles, eliminating the weak', suggesting this was apparent 'among German refugees from eastern Europe during and after the Second World War' (ibid. 290). 
'Push-pull' theories essentially treat migration as the outcome of low socioeconomic status or inseciurity in the sending country, relative to the more affluent and politically stable systems of receiving societies. However, this approach does not explain the larger multi-way flows between more advanced countries, the phenomenon of 'exchange' migration and the return flows that are characteristic of internal and external migration. These theories also fail to account for the specific direction of particular movements and the fact that there is little migration from some of the poorest regions of the world. At the individual level such theories fail to distinguish movers from non-movers in the same localities. Furthermore, they pay little attention to refugee movements as such. Kunz $(1973,1981)$ endeavoured to remedy this by introducing the concept of 'kinetic models' of flight and displacement in which he distinguished between anticipatory and acute refugee movements. He also identified 'vintages', or waves of migration which might be the result of flight from potentially dangerous situations, or directly forced by an army in pursuit, by capture or direct coercion (such as transportation to concentration camps, forced labour etc.). He also noted the phenomenon of displacement by 'absence' which may occur when individuals or groups are unable to return to their own country following a political coup or invasion. He identified stages in the process which might begin in an anticipatory mode, become acute and then be followed by temporary asylum and eventual resettlement (Kunz 1973:145). Kunz (1981) distinguished eleven different types of refugee movement including 'reactive fate-groups' and 'purpose groups'. He pointed out that 'the borderline between political refugees and those dissatisfied economically can be blurred when displacement occurs in reaction to events'. He also suggested that 'self-fulfilling purpose groups' (such as religious minorities determined to maintain their separate identity) may be classified as voluntary migrants (ibid:44-45).

An alternative to the 'kinetic' model is a 'systems' approach, such as that adopted by Mabogunje (1970), Tos and Klinar (1976), Richmond and Verma (1978) and Hoffmann-Nowotny (1981). These writers trace direct links between sending and receiving areas within a regional or global system and combine an examination of factors giving rise to migration with the impact of these movements on the migrants themselves and the receiving society. Portes and Borucz (1989) underlined the importance of a history of prior contact between sending and receiving countries, arising from conquest, trade, imperial-colonial relations and direct recruitment. From these contacts arise complex network connections which influence the scale and composition of migration (Boyd 1989).

Migratory movements, including those defined as 'refugee', are not entirely independent of these prior connections but they are also related to the process of forming modern states and to the violence associated with nationalism and independence movements. Zolberg (1989:403-4) suggested that current migration theories, particularly as they relate to refugees, are 'historical, structural, globalist and critical'. Notwithstanding global inequalities and violence giving 
rise to powerful 'push' factors, massive migrations do not automatically occur. This is because of the restrictive measures imposed by the potential receiving countries wishing to exercise control over their borders. Zolberg et al. (1989:269) identify three 'sociological types' of refugee. They are the activists who are dissenters and rebels forced to flee the regimes to which they are opposed; the targeted refugees who are singled out for violent treatment because of their membership of a particular group; and victims who are accidently caught in a violent situation. The common denominator is the violence which is either instigated by the state or beyond its control. Unfortunately, this categorization is insufficient to account for different behaviour under similarly violent conditions, or for the compelling circumstances inducing migration which are not necessarily 'violent' in the physical sense, but which are nevertheless extremely coercive.

\section{Structuration Theory}

It must be understood that, in sociology, theoretical explanations are necessarily probabilistic, not deterministic. Human agency implies an element of choice and ensures that some degree of uncertainty is always present, even when the choices in question are severely constrained by external conditions. There is no simple cause and effect relationship between a specific event and its consequences. It is unusual to find only univariate determinants of a social phenomenon or process. Normally, multivariate analyses are required in order to understand the aetiology and outcome of events. The variables involved are generally interactive (in the sense that the consequence of event ' $a$ ' may be different in the presence of variable ' $b$ ' than in the presence of variable ' $c$ '). Furthermore, such interaction may be multiplicative (rather than additive), meaning that a combination of circumstances will generate consequences that are more than the sum of the parts. Social actions are reflexive and (at least in part) self-regulating, although there may be unintended and unanticipated consequences. This means that causal relations are recursive, in the sense that subsequent actions may affect previous ones, thereby. having either positive (exaggerating) or negative (inhibiting) effects. This includes policy and programme interventions, which can sometimes have unpredicted results, of either a positive or negative kind. Such a theoretical approach requires a systems methodology. This means that attention must be paid to the interdependence of multiple factors exhibiting varying degrees of congruity and incongruity. Social systems vary widely in the degree to which they exhibit consistent patterning and integration. Internal contradictions (that is, an opposition of structural principles or basic values) may arise. This may lead to system degeneration and collapse, unless corrected by self-regulating institutions such as democratic consultation, mediation and dispute resolution processes (Richmond 1988b:1-14).

A key problem in sociological theory, not confined to the questions of migration, is the relation between social psychological determinants of individual 
motivation, on the one hand, and the structural determinants which influence behaviour, on the other. Most attempts to theorize about migration have separated micro-level analyses of the social psychology of migration decisionmaking from any macro-level examination of structural factors. For example, Wolpert (1965) put forward a theory of migration decision-making based on a 'place utility' model of rational choice and intention. A more complex 'value expectancy' model was developed by De Jong and Gardner (1981), but a review of the empirical research based on this and related theories found its predictive value to be limited (Simmons 1985-86). Recent developments in 'structuration theory', largely influenced by the work of Anthony Giddens (1979, 1984, 1990), help bridge the gap between micro and macro levels of explanation, by emphasizing the importance of human agency in the process of structuring and re-structuring social relations across space and time. Giddens shows that social structures not only constrain behaviour but also enable (Giddens, 1984:173). Cohen (1989:41) notes that Giddens' account of the 'duality of structure' provides a basis for reconciling action and structure. 'It thus represents a dramatic departure not only from prevailing theories of action but also from theories that concentrate upon the properties of social collectivities.'

Giddens emphasizes the importance of ontological security in the formation of identity and the stabilization of social relations. ${ }^{1}$ He draws attention to the ubiquity of risk and danger in the modern world, including global phenomena such as nuclear weapons and environmental risks, and the adaptive reactions people have to these dangers (Giddens, 1990:124-136). Turner $(1987,1988)$ borrowed from Giddens and others in formulating a sociological theory of motivation which emphasizes both conscious and unconscious needs, relating these to the properties of the system within which action occurs. Specifically, Turner emphasizes the importance of group inclusion, trust, security, symbolic and material gratification, self conception and inter-subjective understanding. In turn, these are linked to goal achievement, power and social exchange.

Following this approach, I have argued that there is a continuum between the rational choice behaviour of proactive migrants seeking to maximize net advantage and the reactive behaviour of those whose degrees of freedom are severely constrained:

Under certain conditions the decision to move may be made after due consideration of all relevant information, rationally calculated to maximize net advantage, including both material and symbolic rewards. At the other extreme, the decision to move may be made in a state of panic facing a crisis situation which leaves few alternatives but escape from intolerable threats. Between these two extremes, many of the decisions made by both 'economic' and 'political' migrants are a response to diffuse anxiety generated by a failure of the social system to provide for the fundamental needs of the individual, biological, economic and social (Richmond 1988a:17).

The large majority of international migrants (including those generally regarded as 'refugees') fall somewhere between these extremes. Figure 1 shows 
Figure 1

Structuration of Migration

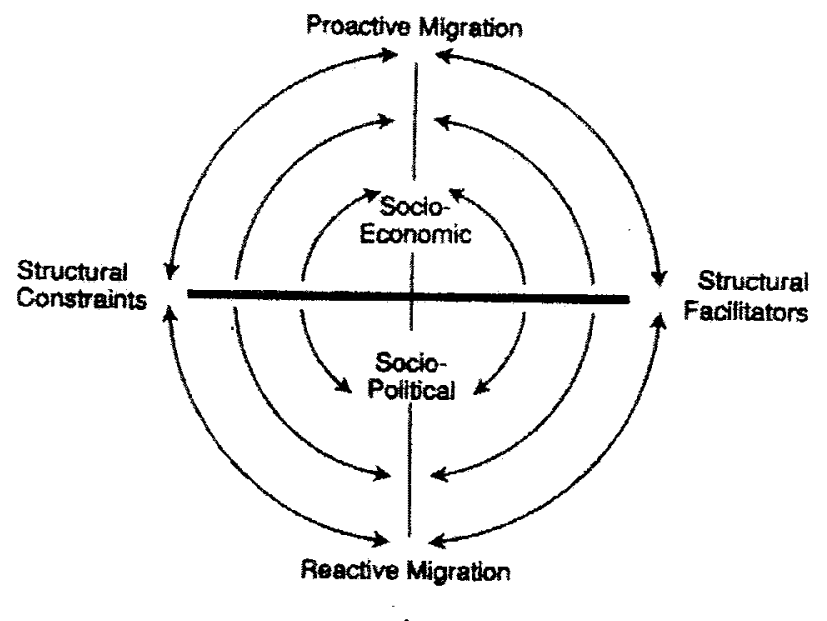

the relationship between proactive and reactive migration on the vertical axis and the structural constraints and facilitating factors on the horizontal axis. The latter include economic, political, social, environmental and biopsychological influences on individual and collective behaviour giving rise to a process of structuration, i.e. the structuring of social relations between migrants and non-migrants across time and space. Examples of typical proactive migrants include professionals, entrepreneurs, retired people and temporary workers under contract. Also proactive are spies, defectors and politically motivated movers in what Kunz calls the 'anticipatory' stage. Reactive migrants include those who meet the UN Convention definition by having a genuine fear of persecution and being unwilling or unable to return, but may also comprise others reacting to crisis situations caused by war, famine, economic collapse and other disasters. ${ }^{2}$ Life-threatening situations undermine ontological security and reactive migration is one adaptive solution. The UNHCR Working Group on Solutions and Protection, identified several categories of persons in need of protection, in addition to those covered by the current UN Convention. They include those forced to leave by natural and man-made disasters, internally displaced persons, stateless persons and those fleeing generalized violence. However, there has been no agreement on a broader definition of a refugee in international law (UNHCR 1991). ${ }^{3}$

\section{Multivariate Model of Reactive Migration}

Some elaboration of the concept of 'reactive migrants' and the factors giving rise to such movements is required, keeping in mind that there is no hard 
and fast line dividing reactive and proactive, although the latter have more options open to them. They have greater freedom in deciding whether to move as well as in their choice of destination and the opportunity of returning. International laws and conventions generally define as 'refugees' only those who have crossed an international border although, from a sociological perspective, they may be indistinguishable from internally displaced persons reacting to similar circumstances. Feelings of group exclusion, loss of trust and a sense of threat and insecurity, can occur independently of each other although one frequently leads to the others. Some combination of political, economic, environmental, social and psychological variables is generally involved. They range from external and internal war, and state-initiated genocidal policies towards minorities, which involve mass extermination, to the effects of volcanic eruptions or earthquakes where the civil authorities are unable to provide the victims with adequate protection or rehabilitation. The inclusion of environmental determinants in this schema reflects a growing recognition that climatic changes, drought and famine are not independent of the socio-political and economic causes of migration, including revolution and civil war. The situation in the sub-Saharan regions, Ethiopia, the Sudan, and Somalia is evidence of this link, as is the effect of drought and crop failure in Bolivia and Peru (Hampson in Mungall and McLaren 1990). The effects of global warming and other ecological disasters in the future could also give rise to a growing problem of 'environmental refugees' (Suhrke and Visentin 1991). The environmental hazards of war, including chemical weapons and oil pollution, about which scientists had previously warned (Westing 1990), were highlighted by recent events in the Persian Gulf.

A multivariate 'systems model' of the relations between these elements in the aetiology of refugee movements is shown in Figure 2. The chart illustrates the interaction between economic, political, social, environmental and biopsychological determinants, on the one hand and, on the other, the importance of distinguishing predisposing factors, structural constraints, precipitating events, enabling circumstances and feedback effects of reactive migration on the states concerned, as well as the global system.

\section{Predisposing Factors}

The above account indicates that political factors are important but not exclusive determinants of reactive migration. Extreme inequalities of wealth and resources between different countries and regions of the world are among the predisposing factors increasing the probability of reactive migration. Such inequalities, when combined with political instability, create the conditions under which refugee movements are likely to occur, unless severely constrained by other factors. New state formation and decolonization, including the rise of nationalist and separatist movements, also provide fertile ground for refugee movements to occur (Zolberg 1989; Smith, 1991). States are generally defined as sovereign organizations having 'supreme coercive power' and a monopoly 
Flgure 2

Reactive Migration: Multivaritte Factor Analysla

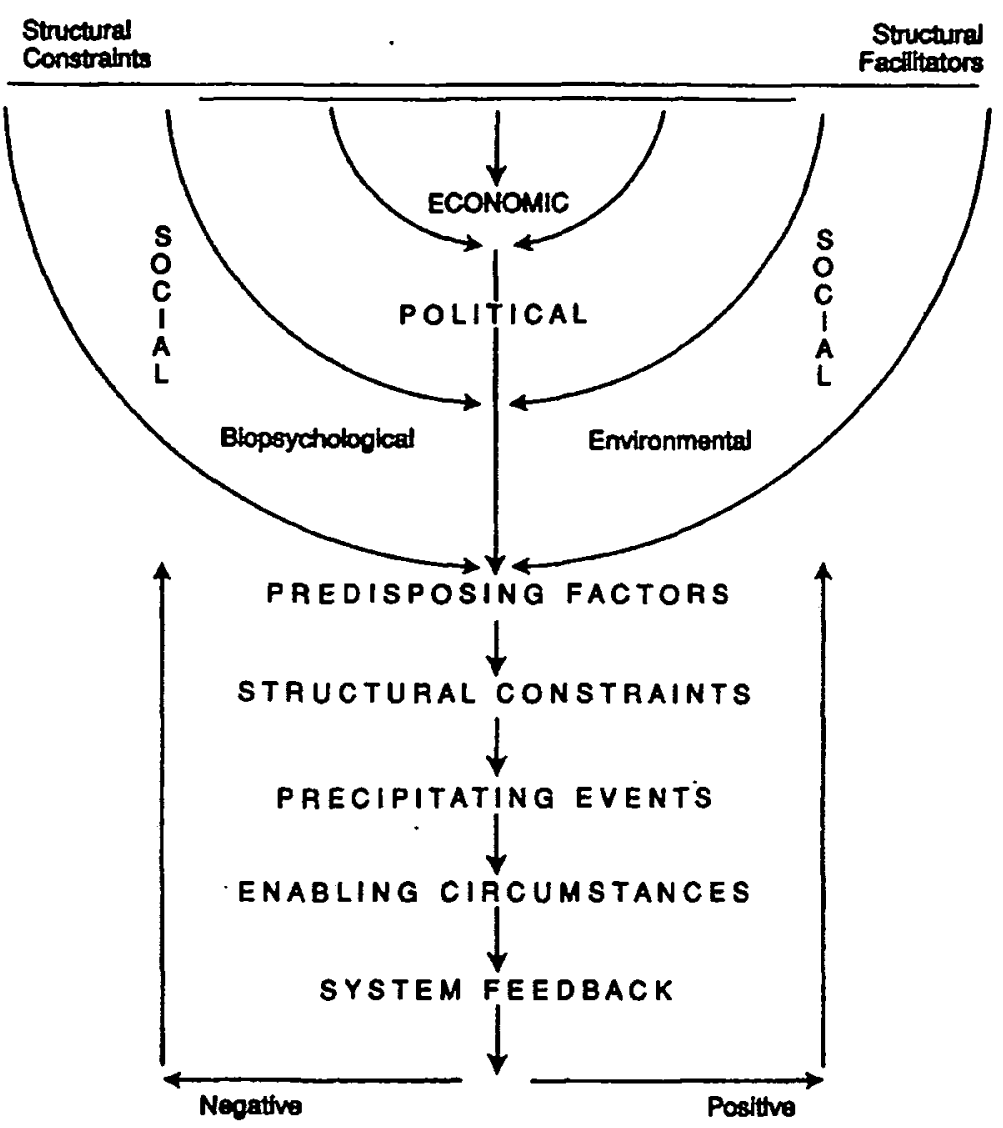

of the legitimate use of violence, for external defence and the maintenance of internal 'law and order'. At the same time it is recognized that states may abuse their powers and that other agencies may also use violence in the pursuit of their goals, with or without the connivance of state authorities, thereby creating the potential for flight from danger.

The boundaries of states have their origin in war, imperial conquest and treaties designed to stabilize a balance of power in a given region. However artificial and lacking in correspondence, either to geographic factors or the ethno-linguistic composition of the population, such boundaries assume a 'sacred' status. The right to defend them is entrenched in international law and attempts to extend them are met with opposition. The ideology of a 
relatively homogeneous 'nation-state' has been used to mobilize support for the defence of existing state boundaries, and for their extension to incorporate neighbouring (and even distant) territories where close allies and friends, fellow nationals or co-religionists reside, supposedly under the domination of alien rulers. In reality, the populations of modern states are generally polyethnic and multi-national in composition (Richmond 1988b:141-66). Ethnic nationalism and aspirations for independence lead to 'wars of national liberation' and revolutions which, in turn, give rise to reactive population movements across borders. Prolonged incarceration in camps can lead to militant 'refugee warriors' and to 'exiles' in their own birthplace (Zolberg et al. 1989; Abu-Lughod 1988).

Numerous commentators have drawn attention to the dangers of the 'militaryindustrial' complex, endemic in twentieth century states, capitalist and socialist, imperial and ex-colonial, developed and developing. President Eisenhower wamed against its propensity to dominate the American economy; $C$. Wright Mills observed the integration of political, economic and military power elites and, more recently, Soviet analyst Georgy Arbotov drew attention to the role of the military in the USSR in opposing glasnost, perestroika and independence movements in the Baltic States and elsewhere (Mills 1956; Kondrashov 1991). The international ramifications and dangers of arms manufacture and distribution were noted by the inventor of dynamite (Alfred Nobel) in 1876, by the Peace Congress in Berne in 1899, by Bernard Shaw in Major Barbara (1905), by the British Admiralty in 1919, a British Royal Commission on the Private Manufacture of and Trading in Arms (1935-36) and by the UN on many occasions since (Myrdal 1976; Samson 1977; Gleditsch and Njolstadt 1990). Firms such as Krupp in Germany and Vickers-Armstrong in Britain supplied arms to both sides in the 1914-18 war, and since then, a world-wide armaments industry has developed in which Third World countries are heavily involved. More recently, the role which western countries and the Soviet Union played in arming Iraq has been highlighted. An estimated \$50 billion worth of weapons and advanced technology (as well as the components for bio-chemical warfare) were sold to Iraq. This is only one segment of the international arms trade (Time Magazine, 11 February, 1991).

The process of 'globalization' has also increased the propensity for reactive migration. In 'mapping the global condition', Robertson (1990:27) suggests that the period since 1960 has been a 'phase of uncertainty'. This phase of globalization has brought with it inherent contradictions arising from the inclusion in the global system of Third World countries, the increase in global institutions and media influence, problems of multiculturism and polyethnicity, concern with humankind as a 'species community', and interest in world civil society and world citizenship. The resolution of these contradictions, and their consequent conflicts, will determine whether an integrated global economy, polity and society can become a reality.

The world-wide 'arms bazaar' may not have been the beginning of the global economic system as we know it today, but it remains a significant component of it. Giddens (1985:255, 293) identifies four major sub-divisions of the 
current world system: (1) A global information system reflecting symbolic orders and modes of discourse; (2) A system of relations between states involving political institutions and a growing number of international agencies; (3) the world capitalist economy and related economic institutions and (4) a world military order enforcing law and imposing sanctions. He rejects the view that globalization necessarily leads to a complete loss of sovereignty. 'Since states exist in an environment of other states, "power politics" have inevitably been a fundamental element of the geo-political make-up of the state system' (ibid. 292).

\section{Structural Constraints}

The persistence of quasi-sovereign states intent on protecting their borders against illegal migrants and other unwanted persons (such as drug dealers, smugglers and other criminals) is among the factors constraining the movement of reactive migrants. Although economic and other influences (including mass communications) may transcend state boundaries, there are powerful political forces reinforcing borders and controlling population movements across them. There is a contradiction between the long run trend of the global economy toward a 'borderless world', which Ohmae (1990:xii-xiii) describes as 'ensuring the free flow of Information, money, goods and services as well as the free migration of people and corporations', and the reality of a world of 'closed borders' and 'reluctant hosts', shutting the doors to refugees and all but a select few economic migrants (Dowty 1987; Joly and Cohen 1989; Matas and Simon 1989; Richmond 1991). There is a similar contradiction between the right to emigrate which is entrenched in the UN Declaration of Human Rights and the lack of any corresponding obligation on the part of states to admit anyone seeking entry. On the contrary, the right to refuse entry is regarded as inherent in the concept of sovereignty. As a result there are large numbers of 'stateless persons' and 'refugees in orbit'.

States continue to pursue policies which they regard as in their own collective self-interest, including the protection of their economic system and the standard of living of their own citizens. In the case of the more industrially developed countries these standards include the provision of health and welfare services, unemployment insurance and pension plans, income maintenance programmes, educational services and minimum housing standards. Uncontrolled immigration, including the admission of large numbers of refugees, is seen as potentially threatening these standards. In this respect the immigration control measures instituted resemble the actions of the South African government when apartheid was enforced. Pass laws, work permits, segregated housing locations, restricted travel, deprivation of voting and other citizenship rights, removal to 'Homelands', and draconian enforcement measures have all been used by governments against illegal immigrants and asylum seekers.

The situation has been aggravated by recent developments in eastern Europe. As long as the Berlin Wall metaphorically separated Warsaw Pact countries 
from those in the NATO Alliance, and the countries of eastern Europe and the Soviet Union placed severe restrictions on emigration, western European countries (together with the USA, Canada and Australia) were prepared to recognize as 'refugees' almost anyone who wished to leave a communist country, whether their motivation was economic or political. The reverse is now the case. Given the severe economic crisis in eastern Europe, and the lifting of the ban on exit, there is potential for an enormous exodus. Ethric conflicts in the former Soviet Union, nationalist movements in the Baltic states, Yugoslavia and elsewhere, together with evidence of growing anti-semitism, racism and xenophobia in Europe (west and east), all create the conditions for substantial reactive migration. In the face of these potential pressures toward 'mass migration' from eastern to western Europe a variety of control measures are being put in place to deter and limit both proactive and reactive migrants. Not only are western European countries restricting entry but countries such as Poland have been obliged to control the movement of Romanians and are afraid that there could be a large exodus from the Soviet Union, if conditions deteriorate further there. Some Albanians, seeking to escape repressive political, as well as deteriorating economic conditions, recently fled to Italy. Western European countries, together with the USA, Canada and Australia, have tried to formulate a common response to these emerging crises.4

Other structural constraints which serve to limit the actual incidence and scale of reactive migration are the emigration laws of potential sending countries and the use of coercive measures on either, or both, sides of state borders to deter such movements. Armed border guards prepared to shoot, strict deportation measures for illegal migrants, and coast guards who intercept boats carrying potential refugees, are among the most obvious examples. While all forms of authoritarian repression may add to the predisposition to migrate, those same repressive laws and totalitarian measures make actual flight more difficult. At the same time, critical turning points in the history of such societies may precipitate long suppressed aspirations to escape.

\section{Precipitating Events}

Sudden changes in the economic, political, social or environmental situation may precipitate reactive migration. Critical events include the outbreak of war, internal revolution or the institution of racist or religious programmes and genocidal policies. Outbreaks of terrorist activity by dissident or separatist groups or other sources of violent conflict may be involved. Reactive migration may also be precipitated by natural and technological disasters which destroy food supplies or housing, threatening the life, health and livelihood of local residents. Generally, the precipitating event is one that disrupts the normal functioning of the system and thus destroys the capacity of a population to survive under the prevailing conditions. The social systems which provide people with an ongoing sense of ontological security may collapse in the 
face of what Giddens (1990:171) calls the 'high consequence risks of modernity', such as ecological disaster, economic collapse, war, nuclear threats, the coming to power of a military dictatorship, or the end of a totalitarian regime.

\section{Enabling Circumstances}

Not all predisposing factors and precipitating events actually generate large scale reactive migration although some proactive movements may occur under these conditions. Some additional enabling circumstances are needed. These are generally the obverse of the structural constraints already discussed. Thus, the end of a dictatorial regime and the relaxing of border controls may make reactive migration feasible. Extreme poverty remains a deterrent because the migrants must have access to some resources to provide for their journey and for their interim support. Often bribes must be paid, documents acquired, tickets bought and provisions obtained. Reactive migration may be demographically and economically selective, favouring the young, the healthy, the able-bodied and those with some material resources that can be traded or converted into foreign currency. It may also be gender selective as adult males may be more proactive than women and children, who are often left behind with few options, except to react to circumstances outside their control.

Other enabling circumstances depend on the actions of governmental and non-governmental agencies who may institute rescue missions, establish refugee camps, issue travel documents, relax entry requirements and set up asylum application procedures. Generous immigration programmes and steps to promote human rights by international agencies may also facilitate reactive migration and eventual resettlement.

\section{System Feedback}

The processes of structuration occurring as a consequence of reactive migration, and the response of individuals and collectivities to such movements, have positive and negative feedback effects on the societies in question, and on the global system of which they are a part. Under some conditions reactive migration may grow at an exponential rate until it reaches a level that is perceived as threatening to the stability of receiving countries, which then institute measures to deter and restrict further arrivals. Such countries may experience a 'backlash' by their own population against further immigration. There may be efforts to deport those not meeting strict standards of eligibility for refugee status. Voluntary and involuntary repatriation schemes may be instituted.

As the number of reactive migrants (whether legally defined as Convention refugees or not) reaches the levels currently estimated as $16,797,200$ refugees and asylum seckers and a further 20 million internally displaced civilians (US Committe 1991), attention turns to questions of 'root causes' and preventative action. Clearly, as the above analysis shows, there are no simple solutions. However, measures which reduce economic inequality and 
dependency, promote political stability and democratization, achieve arms control and de-militarization and facilitate the peaceful settlement of disputes all contribute, in the long run, to a reduction in scale of the problem. Failure to do so results in whole generations who are born, live and die in transit camps. The insecurity created under these conditions may lead to the formation of militant protest groups and 'refugee warriors' ready to fight for their individual and collective human rights.

\section{Typology of Reactive Migration}

Using the multivariate approach outlined above it is possible to delineate a typology of reactive migration as shown in Figure 3.

The horizontal dimension of the figure lists the major determinants of particular kinds of reactive migration and the left hand (vertical) column indicates the principal secondary factors reinforcing the breakdown in institutions previously providing political protection, economic support and a sense of group inclusion, trust and security. Major determinants include the precipitating events discussed above, together with enabling circumstances,

Figure 3

Reactlve Migration: Typology

\begin{tabular}{|c|c|c|c|c|c|}
\hline & POUTICAL & ECONOMIC & ENVIRONMENTAL & SOCIAL & BIOPSYCHOLOGICAL \\
\hline POLITICAL & 1 & 2 & 3 & 4 & 5 \\
\hline ECONOMIC & 6 & 10 & 14 & 18 & 22 \\
\hline $\begin{array}{l}\text { ENVIRON- } \\
\text { MENTAL }\end{array}$ & 7 & 11 & 15 & 18 & 23 \\
\hline SOCIAL & 8 & 12 & 16 & 20 & 24 \\
\hline $\begin{array}{l}\text { BIO } \\
\text { PSYCHO- } \\
\text { LOGICAL }\end{array}$ & $\theta$ & 13 & 17 & 21 & 25 \\
\hline
\end{tabular}


while principal secondary factors include the predisposing factors, although in particular cases there may be interaction between all of these. The categories thus created do not preclude the possible added effects of tertiary factors which may be present, or of overlapping categories and concomitant or sequential calamities, increasing the propensity to migrate. In categories one to nine, political determinants are involved either as primary or secondary determinants of movement. These types of reactive migration are generally more readily recognized as 'refugee movements' than others.

1. Political/political: In this category are people fleeing from war-torn countries, whether the war is a result of external invasion or internal civil conflict. Political exiles, the potential victims of state-induced genocidal policies, nationalist movements, ethnic conflicts and death threats to minorities are also included. The largest single example today comprises Afghan refugees in Pakistan and Iran as well as those internally displaced in Afghanistan. Recent events in the former Yugoslav Republic have also generated large reactive migrations as a result of political conflicts.

2. Political/economic: This comprises those compelled to move as a result of slave trading and other forms of forced labour, backed by coercive laws and quasi-military threats, including the forcible recruitment of children into military service. The UN Working Group on Contemporary Forms of Slavery monitors this type of reactive migration.

3. Political/environmental: Included are victims of nuclear and bio-chemical weapons or of accidental nuclear and bio-chemical disasters that are the direct or indirect result of governmental policies and programmes, including failure to enforce appropriate safety standards. The Chernobyl nuclear disaster is one example which resulted in the evacuation of the exposed population. Kurdish refugees escaping chemical weapons used by Iraq is another.

4. Political/social: Comprises those escaping from political regimes perpetrating major human rights violations of the kind identified by agencies such as Amnesty International, e.g. mass executions, 'disappearances', systematic terrorism. The activities of the Sendero Luminoso in Peru are an example. Individual migrants may not always meet the UN Convention definition of a 'refugee', if they cannot show that they personally are at risk.

5. Political/bio-psychological: Includes those individuals threatened with execution, torture, brain-washing, or 'cruel and unusual' punishment, for political protest, crimes against the state etc. Those escaping imprisonment under the Stalinist regime or Communist China are examples.

6. Economic/political: Persons forced to move by government backed policies of forced re-location, transmigration, clearances etc. are in this category. Thailand's program of reforestation by forced eviction is an example (Hubbel and Rajesh 1992). Also, migration necessitated by compliance with externally imposed 'structural adjustment' programimes designed to satisfy requirements for international loans and aid. 
7. Environmental/political: Includes migration induced by politically motivated actions that result in environmental disaster, e.g. deliberate oil spills, fires, water or air pollution, and/or famine conditions resulting from civil conflict. Refugees and internally displaced persons in the Sudan and Somalia are examples (Otunnu 1992).

8. Social/political: Escape from general deprivation of human rights, civic, social and economic, as in totalitarian regimes, or from South Africa under apartheid, are examples.

9. Bia-psychological/political: Includes migration induced by 'psychological warfare', terrorism or widespread 'hate-mongering' toward particular ethnic or religious minorities. Examples include Tibetan monks in Nepal fleeing Chinese persecution of those suspected of pro-independence sympathies.

10. Economic/economic: Persons forced to migrate as a result of bankruptcies, total economic collapse, chronic unemployment and loss of livelihood, without 'safety-net' social security measures, are in this category. Recent developments in eastern Europe and periodic economic crises in developing countries have induced such economically motivated reactive migration.

11. Economic/environmental: Comprises migration induced by the effects of de-forestation, deliberate flooding, open-cast mining, hydro-electric dams, or other economic actions causing environmental damage. The internal displacement of aboriginal populations in Canada following the James' Bay hydro-electric project is an example.

12. Economic/social: Migration induced by structural changes in the economy leading to rural de-population, urbanization, regional disparities etc. falls into this category. Loss of livelihood due to international frectrade agreements and industrial re-locations are examples.

13. Economic/bio-psychological: Closure of mines or other economic enterprises following major accidents, together with occupational health hazards and injuries may result in reactive migration.

14. Environmental/economic: Includes population movements consequent upon drought, soil depletion etc., with consequent famine conditions. In 1992, Zimbabwe and other areas in southern Africa were facing a desperate water shortage and mass starvation which resulted in reactive migration.

15. Envinonmental/environmental: Migration compelled by earthquakes, volcanic eruptions or other 'natural' disasters are included here, although a neglect to take precautionary measures may be a tertiary factor.

16. Environmental/social: Migration following loss of livelihood induced by 'animal rights', 'anti-fur trapping' and general conservationist policies. Ironically, some populations may be forced to move as a consequence of policies adopted by the recent 'Earth Summit' conference, designed to combat over-fishing, destruction of rain forests etc. 
17. Environmental/bio-psychological: This includes migration induced by soil, water and air contamination by pollutants, 'total allergy syndrome', etc. People may be forced to move as a result of anticipated radiation hazards, lead poisoning etc. particularly if children are affected.

18. Social/economic: This includes migration induced by strikes, lockouts, curfews, boycotts, social unrest etc. Escape from riot-prone inner city areas to safe suburban neighbourhoods is an example.

19. Social/environmental: Migration may be induced by a threat to life-style, loss of 'roots', desire for preservation of community etc., in the face of industrialization, urban sprawl, or encroachment on rural areas, leading to a re-establishment of 'traditional' ways. Although often individually proactive, such movements may be reactive when whole communities are affected.

20. Social/social: Migration may be impelled by laws and customs which enforce racial or ethno-religious discrimination and segregation, forbid inter-marriage etc., or motivated by existence of racially reserved occupations, deprivation of access to education or qualifications, and social mobility blocked for minorities.

21. Social/bio-psychological: Includes migration induced by age or gender discrimination, language loss, 'cultural genocide', forced assimilation etc.

22. Bio-psychological/economic. This category covers migration necessitated by industrial injuries, physical and mental health disabilities, occupation stress and 'burn-out' etc. which render the person incapable of economic self-support in the previous location.

23. Bio-psychological/environmental: Migration caused by plagues, epidemics such as cholera, or other major health hazards, is included here.

24. Bio-psychological/social: Escape from race prejudice, anti-semitism, and other forms of ethno-religious intolerance or abuse (not institutionalized in the political or economic system) belongs in this category.

25. Bio-psychological/bio-psychological: Includes flight from eugenic or psychiatric experimentation, brain-washing, indoctrination etc. Also, escape from spousal abuse and violence, sexual assault, child abuse or domestic or institutional violence is included.

As noted above, there is a continuum between proactive and reactive migration, in all of the above cases, but the structural constraints are greater in the latter, and the scope for rational choice behaviour by reactive migrants is limited.

\section{Policy Conclusions}

The above is more than just a list of the traditionally understood 'push' factors contributing to migration because it recognizes the interaction between motivational factors, on the one hand, and the social structural determinants, on the other. It also emphasizes the complex interaction between political, 
economic, environmental, social and bio-psychological factors in determining the propensity to migrate. Thus it demonstrates the inadequacy of any definition of a 'refugee' which singles out one element in the causal chain, such as having a 'genuine fear of persecution', because such fear is often only one factor in a much more complicated relation between predisposing factors, structural constraints, precipitating events and enabling circumstances.

In the context of an emerging 'new world order', the policies which should be adopted toward refugees, and other reactive migrants, are those which ensure the viability of a global social system. States can no longer isolate themselves, geographically, economically, politically or socially, from the actions of other collectivities. Whether it is the effect of destroying the rain forests or building dams, inducing large scale unemployment through externally imposed monetary policies, the accumulation of agricultural surpluses in one region while famine reigns in another, the military invasion of one state by another, violent revolution or nationalist insurrection, the persecution of ethnic, religious or political minorities, or fall-out from a nuclear disaster - all of us are implicated in the causes and directly affected by the outcomes.

Mass migration (not just in Europe but world-wide) will be a major force for change and a potential source of disastrous conflict in the future, unless our dominant values, and the policies based on them, are radically changed. We must recognise that our postmodern society is a global one, the survival of which requires the institutionalization of universal values respecting human rights, including the right to asylum. It is imperative that the definition of a 'refugee' be widened to include all those in peril from natural and unnatural disasters. It is also essential that the political will and the means be created to end the global 'arms bazaar', together with the violent conflicts that it sustains. Innovative responses from the international community, through the UN and its various agencies, will be needed to ensure reflexive self-regulation. It will be necessary to determine priorities, develop rules, allocate resources and take appropriate preventive and rehabilitative action, creating new global structures.

1. Giddens (1984:375) defines ontological security as "Confidence or trust that the natural and social worlds are as they appear to be, including the basic existential parameters of self and social identity'. Political, economic, social, psychological and biological security may be seen as dimensions or sub-sets of ontological security.

2. The large majority of international migrants, including those sometimes described as 'economic refugees', fall somewhere near the middle of the proactive-reactive continuum. Family sponsored migrants and assisted relatives are generally proactive, except when the family members in question have no practical alternative to joining their kin in another counțry.

3. Canada is among the countries resisting any widening of the Convention definition of a refugee, on the grounds that to do so would dilute already limited funds and disadvantage those whose need is most acute (UN Executive Committee of the High Commission for Refugees, Oeneva, 7 -October, 1991). Unfortunately, the 1951 Convention fails to address contemporary realities and does not necessarily identify all those most seriously threatened. 
4. An inter-governmental agency, 'Consultations on Asylum, Refugee and Migration Policies in Europe, North' America and Australia', is based in Geneva. The participating states are Australia, Austria, Belgium, Canada, Denmark, Finland, France, Germany, Italy, Netherlands, Norway, Spain, Sweden, Switzerland, the UK and USA. Several of these countries have recently introduced new immigration legislation and some are parties to the Schengen and Dublin Conventions, 1990. The aim is to 'harmonize' policies regulating population movement.

ABU-LUGEOD, J. (1988) 'Palestinians: Exiles at Home and Abroad', Current Soctology, 36, (2), pp. 61-70.

BOYD, M. (1989) Tamily and Personal Networks in Intermational Migration: Recent Developments and New Agendas', Intemational Migration Review, 23, (3), pp. 638-670.

COEEN, I. J. (1989) Structuration Theory: Anthony Giddens and the Constitution of Social Life, London, Macmillan.

DE JONG, G. and GARDNER, R. W. (1981) Mgration Deciston Making: Multidisciplinarg Appraaches to Micro-level Studies in Developed and Developing Countries, New Yark, Pergamon Preas.

DOWTY, A. (1987) Clased Borders: The Contemporary Assoult on Freedom of Movement, New Haven, Yale Univeraity Press.

FAIRCBmD, H. P. (1925) Immigration: A World Wide Movement and its A merican Significance, New York, Macomillan.

GDDENS, A: (1979) Central Problems in Sacial Theory: Action, Structure and Contradiction in Social Anabssis, London, Macmillan.

-(1984) The Constirution of Soctety, Cambridse, Polity Press.

-(1985) The Nation-State and Violence: Vol. 2. A Contemporary Critique of Historical Materiallsm, Cumbridge, Polity Press.

- (1990) The Consequences of Modernity. Cambridge, Polity Press.

GLEDITSCH, N. P. and NJOLSTADT, O. (eds) (1990) Arms Racax: Tectmological and Political Dynomics, Newbury Park, CA, Sage.

HAMPSON, F. O. (1990) 'Peace, Security and New Forms of International Govenance', in Mungall, Constance and Melaren (eds) Planer Under Stress: The Challenge of Global Change, Torouto, Oxford Universtity Press.

HOFTMAN-NOWOTNY, H. J. (1981) 'A Sociolorical Approach Towards a General Theory of Migration', in Kritz, M. M., et al. (eds) Global Trends in Migration, New York, Center for Migration Studies.

HUBBER, D. and RAJESE, N. (1992) 'Not Secing the People for the Forest: Thailand's Program of Reforestation by Forced Eviction', Refuge 12, (1), pp. 20-21.

JACKSON, J. (ed.) (1969) Saciologtcal Studties 2: Migration, Cambridge, Cumbridge University Press.

JOLY, D. and COBEN R. (ods) (1989) Retuctant Harts: Europe and Its Refuges, Aldershot, Avebury.

KONDRMSBOV, 8. (January, 15, 1991) 'Domestic Issues Piace Shackles on Soviet Fordign Policy', Las Angeles Times, $\mathrm{H} 2$.

KUN2, E. (1973) The Refugee in Fight: Kinetic Models and Forms of Displecement', Internotional Migration Reviow, 7, (2), pp. 125-146.

- (1981) 'Exile and Resettlement: Refugee Theory', International Mgration Review, 15, (1), pp. 42-51.

LEE, E. (1969) 'A Theory of Migration' in Jackson, J. (ed.) Sactological Sructies 2: Mlgrotion, Cambridge, Cambridge Univeraity Press.

MABOCUNJE, A. L. (1970) 'Systems Approact to a theory of nural-urben migration', Geographical Analysts, 2, (1), pp. 1-18.

MATAS, D. and SDMON, L (1989) Clating the Doars The Failure of Refugee Protection, Toronto, Summerhill Press.

MIIIS, C. W. (1956) The Power Elite, New York, Oxford University Press.

MYRDAL, A. (1976) The Geme of Disarmament: How the United States end Rusia Run the Ams Race, New York, Pantheon Books. 
OHMAE, K. (1990) The Barderless World: Power and Strategy in the Interlinked Economy, New York, Herper.

OTUNNU, O. (1992) 'Enviromental Refugees in Sub-Saharan Africa: Causes and Effects', Refuge, 12, (1), pp. 11-14.

PETERSEN, W. (1958) 'A General Typology of Migrution', American Sociological Review, 23, (3), pp. 256-65.

PORTES, A. and BOROCZ, J. (1989) 'Contemporary Immigration: Theoretical perspectives on its Determinants and Modes of Incorporation', Intemetional Migration Review, 23, (3), pp. 606-630.

RICEMOND, A. H. (1988a) 'Sociological Theories of International Migration: The Case of Refugees', Current Sociolosy, 36, (2), pp. 7-26.

-(1988b) Immigration and Ethnic Confict, London, Macmillan.

- February, 1991) 'International Migration and Global Change', paper presented at a conference on 'Migration', National University of Singapore.

RICHMOND, A. E. and VErMA, R. B. P. (1978) 'The Economie Adaptation of Immigrants: A New Theoretical Perspective', Intemational Migration Review, 17, (1), pp. 3-28.

ROBERTSON, R. (1990) 'Mapping the Global Condition: Globetization as the Central Concept', in Featherstone, M. (ed.) Globol Culture: Nationaliom, Glabalizetion and Modemity, London, Sare. SAMSON, A. (1977) The Arms Bozear, London, Hodder \& Stoughton.

SIMMONS, A. B. (1985-6) 'Recent Sturties in Place. Utility and Intentions to Migrate in Internations? Comparison', Population and Environment, 8, (1-2), pp. 120-41.

SMTTH, A. D. (1991) National Identity, Harmondsworth, Penguin Books.

Sororin, P. A. (1942/1968) Man and Soctety in Calamity: The Effects of Wor, Revolution, Famine, Pestilence upon Human Mind, Behaviour, Social Organtzation and Cultural Lffe, New York, Dutton, (repr. Oreenwood).

SUBRKE, V. and VINSENTIN, A. (September, 1991) 'The Environmental Refugee: A New Approact', Ecodecision, pp. 73-74.

TIME MAGAXTNE (1991) Jill Smolowe, 'Who Armed Baghdad?', 11.12.91, pp. 34-35.

TOS, N. and KLINAR, P. (1976) 'A Systems Model for Migration Research: Yugoslav Workers in the Federal Republic of Cermany, in Richmond, A. H. (ed.) Intemetional Migration and Adaptation in the Modern World. Toronto, ISA Research Committee on Migration.

TURNER, J. H. (1987) 'Toward a Sociological Theory of Motivation', Americon Sociological Review, 52, (1), pp. 15-27.

-(1988) A Theory of Social Intenaction, Stanford, Stanford University Press.

UNITED NATIONS, Centre for Human Rights. (1990) Human Rights: United Nations Training Course an Intemational Norms and Standard in the Freld of Human Rights. Proceedings, Moscow (USSR), 27 November-1 December. 1989, New York, United Nations.

High Commissioner for Refuges (1991) Report of the Working Group on Solutions and Protection, Geneva, Executtive Committec, UNHCR.

US COMMITTEE FOR REFUGEBS (1991) World Refugee Report, 1991, Washington, American Connell for Nationalities Service.

WESTING, A. B. (ed.) (1990) Environmental Harards of War: Releasing Dangerous Fonces in an Inctustrialting World, Newbury Park, CA, Sage.

WOLPERT, J. (1967) 'Behavioral Aspects of the Decison to Migrate', Pappers of the Regional Sclance Assactation, 19, pp. 159-169.

ZOLBKRG, A. (1989) 'The Next Waves; Migration Theory for 8 Chenging World', International Mignotion Review, 23, (3), pp. 403-430.

-, SUHRKE, A. and AGUAYO, S. (1989) Excape from Volence: Conflict and the Refugee Crists in the Deweloping World, New York, Oxdord University Press.

MS received November 1991; revised MS received August 1992.

- This is an extensively revised version of a paper presented at conferences held at the Centre for Refugee Studies, York University, Toronto, May, 1991, at the Institute for Applied Systems Analysis, Vienna, March, 1992 and the International Sociological Association, Research Committee on Migration, in Lisbon, April, 1992. The author is indebted to discussants at these meetings, the Editor of this journal and two anonymous referees, for valuable suggestions. 